J. Japan. Soc. Hort. Sci. 47(2) : 188-194. 1978.

\title{
Studies on Self-incompatibility of Hyuganatsu, Citrus tamurana Hort. ex Tanaka
}

\author{
I. Pollen Behavior on Stigmas and Pollen Tube Growth in Styles \\ Observed under a Scanning Electron Microscope and a \\ Fluorescent Microscope
}

\author{
Kensuke Yamashita \\ College of Agriculture, Miyazaki University, Miyazaki
}

\begin{abstract}
Summary
In the present experiment, some observations with the morphological and histological aspects were made concerning self-incompatibility in Hyuganatsu, Citrus tamurana Hort. ex Tanaka. The results are summarized as follows.

1. By means of scanning electron microscopy, the pollen behavior on stigmas when self-pollinated was compared with that when cross-pollinated with Hassaku, Citrus hassaku Hort. ex Tanaka. Soon after cross-pollination, the pollen grains began to be coverd by the stigma exudate; 12 hours after pollination, the pollen grains were completely covered by the exudate. While the self-pollinated pollen grains were not covered by the exudate so soon as in the case of cross-pollination, and individual pollen grains were observed rather clearly in some parts of the stigma even 12 hours after pollination.

2. By means of fluorescent microscopy, the pathway of pollen tubes in styles was examined. In the upper portion of styles, the pollen tubes grew not only in the stylar canal along the wall of stigmatoid cells but also through the intercellular space of parenchymatous tissues. In the middle and lower portions of styles, all the pollen tubes grew in the stylar canal along the wall of stigmatoid cells.

The pollen tubes of Hassaku reached the upper, middle and lower portions of the styles in 1,3 and 5 days after pollination, respectively. On the 5 th day after pollination, some pollen tubes were observed to have penetrated into ovaries. While, almost all the pollen tubes of its own did not reach the uppermost portion of the style even 7 days after pollination.
\end{abstract}

\section{Introduction}

Miwa studied to find out the cause of poor bearing in Hyuganatsu for more than ten years, and came to the conclusion that it should be due to its high self-incompatibility as well as to its less ability of parthenocarpy (6). Based on these observations, he suggested that some pollinizers should be interplanted in the orchard of Hyuganatsu in order to secure a stable production. Besides, he made a microscopic observation to know the difference of the pollen behavior in pistils between self- and cross-pollination. He pointed out that the germination of pollen grains in self-pollination was less vigorous than in

Received for publication September 21, 1977 cross-pollination. He also stated that pollen tubes grew through the conductive tissue in the periphery of the vascular bundles and penetrated into ovaries within 7 days even in the self-pollination.

However, data recently reported on citrus incompatibility $(4,8,10)$ raised some questions about Miwa's data, especially on the location of the conductive tissue as well as the growth rate of pollen tubes in styles 'after self-pollination. The present experiment was carried out to reexamine Miwa's results by means of fluorescent microscopy as well as scanning electron microscopy.

\section{Materials and Methods}

Several trees of Hyuganatsu, Citrus tamura- 
na Hort. ex Tanaka, and Hassaku, C. hassaku Hort. ex Tanaka, cultivated in the experiment orchard of Miyazaki University were used for the present investigation.

1. Observation of the pollen behavior on stigmas

Sixty cuttings of flower-bearing shoots of Hyuganatsu which were to open the next day were placed in beakers containing tap water under laboratory conditions. Thirty flowers were emasculated and pollinated with the pollen grains of Hyuganatsu itself, while other 30 emasculated flowers were pollinated with the pollen grains of Hassaku. In either pollination, 10 pistils were picked 2, 5 and 12 hours after pollination, respectively. The fixation and preparation of the samples for scanning electron microscopy were followed by

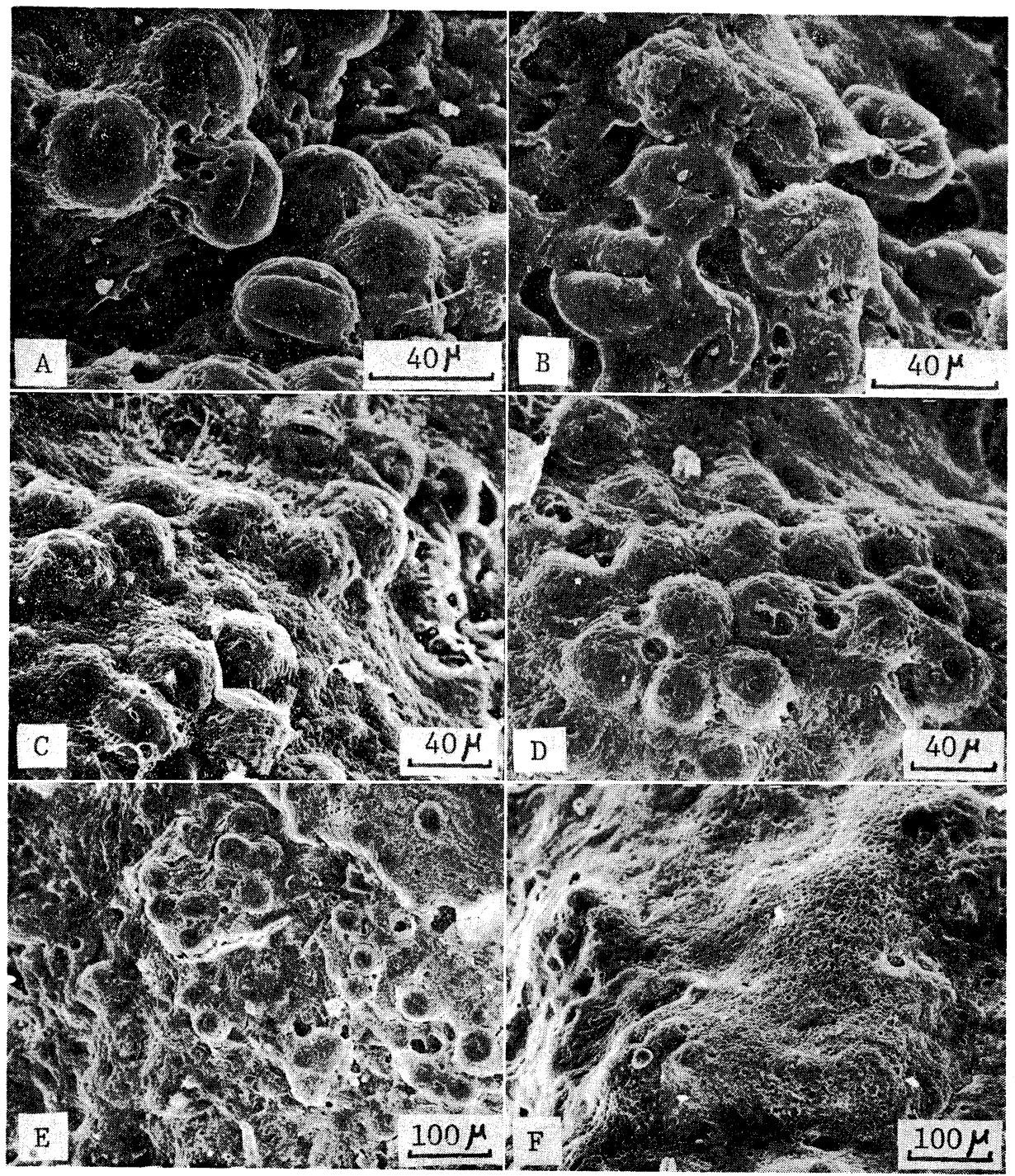

Fig. 1. Pollen behavior on stigmas in self-pollination as well as in cross-pollination.
A. Two hours after self-pollination $(\times 750)$.
B. Two hours after cross-pollination $(\times 750)$.
C. Five hours after self-pollination $(\times 500)$.
D. Five hours after cross-pollination $(\times 500)$.
E. Twelve hours after self-pollination $(\times 200)$.
F. Twelve hours after cross-pollination $(\times 200)$. 
the procedure of Shiraishi et al (9). The Hitachi Critical Point Drying Chamber was used for dehydration of the samples(7). The JFC Ion Sputter was used for Au ion sputtering onto the samples, and the JSM P 15 $\mathrm{BE}$ scanning electron microscope was used for the observation of the samples.

2. Observation of pollen tube growth in stigmas and styles

One hundred and twenty flowers of Hyuganatsu which were to open the next day were emasculated, and one half of the emasculated flowers were pollinated with the pollen grains of its own, while the other half were pollinated with pollen grains of Hassaku. After pollination, all the flowers were covered with paper bags to prevent from contamination by foreign pollen grains. In either pollination, 15 flowers were picked $1,2,3,5$ and 7 days after pollination, respectively. All the pistils were fixed in the Farmer solution for 6 hours and preserved in 70\% alcohol. For fluorescent microscopy, two kinds of preparation technique were used ; one was the freezing microtome sectioning of the fixed sample with a thickness of $30 \mathrm{~m} \mu$ and the other was the squashing of stigmas and styles. For better preparation, the stigmas and styles were softened by immersing them in $8 \mathrm{~N} \mathrm{NaOH}$ solution for 24 hours. All the preparations were stained by Martin's procedure (5) and observed with a Nikon FS-4 fluorescent microscope.

\section{Results and Discussion}

1. Pollen behavior on stigmas in self-and cross-pollination

Fig. 1 shows the pollen behavior on stigmas 2,5 and 12 hours after pollination. Two hours after pollination, the pollen grains began to be covered by the stigma exudate. But, the germination furrow of the pollen grains was still observed rather clearly in both self- and cross-pollinations (Fig. 1, A and B). No difference was observed as to secretion of the stigma exudate between self- and crosspollination.

Five hours after pollination, however, a slight difference was noticed between self- and cross-pollination (Fig. 1, C and D). The secretion of the stigma exudate was less in

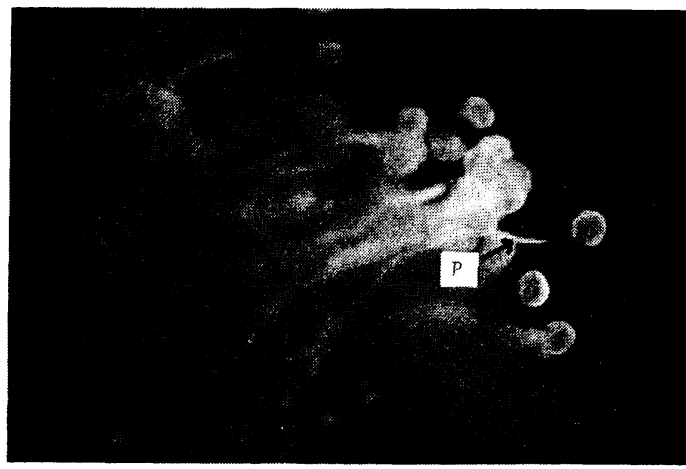

Fig. 2. Pollen germination on a stigma of Hyuganatsu one day after self-pollination. P : Pollen tube.

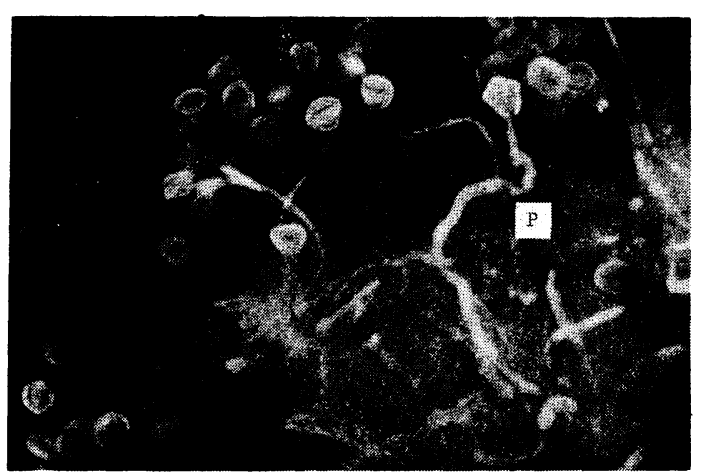

Fig. 3. Pollen germination on a stigma of Hyuganatsu one day after cross-pollination. $\mathrm{P}$ : Pollen tube.

self-pollination than in cross-pollination. But, the germinating pore of the pollen grains was completely covered by the stigma exudate in either pollination.

Twelve hours after pollination, the pollen grains in cross-pollination were covered by the stigma exudate, and it was impossible to observe where they were located (Fig. 1, E). On the contrary, the pollen grains in selfpollination were still observed rather clearly on some parts of the stigma (Fig. 1, F).

Fig. 2 and 3 show the pollen germination on stigmas in both self- and cross-pollinations. The germination of the pollen grains was found to be more vigorous in cross-pollination than in self-pollination, as was observed by Miwa (6).

The stigma exudate in citrus secreted at the flowering time is known to play an important role for pollination and pollen germination (8). As the stigma exudate is very viscous, it serves to catch and hold the pollen grains carried by insects. The stigma exudate also 


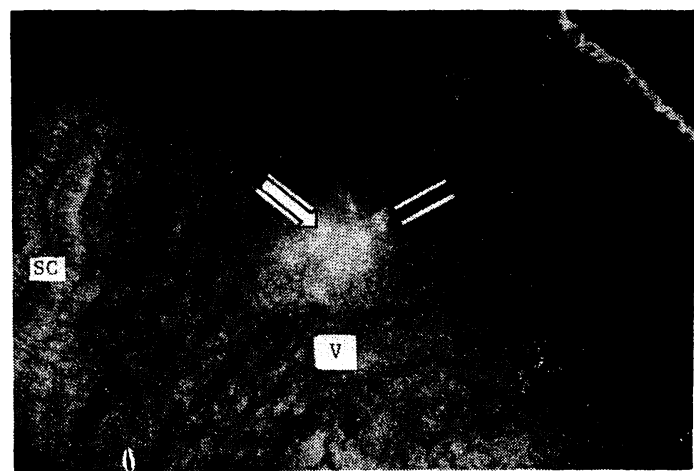

Fig. 4. A transverse section from the upper portion of an unpollinated style in Hyuganatsu. $\Rightarrow$ shows grain-like entities shining yellowish. $\Rightarrow$ shows tube-like entities shining bluish. SC : Stylar canal, V : Vascular bundle.

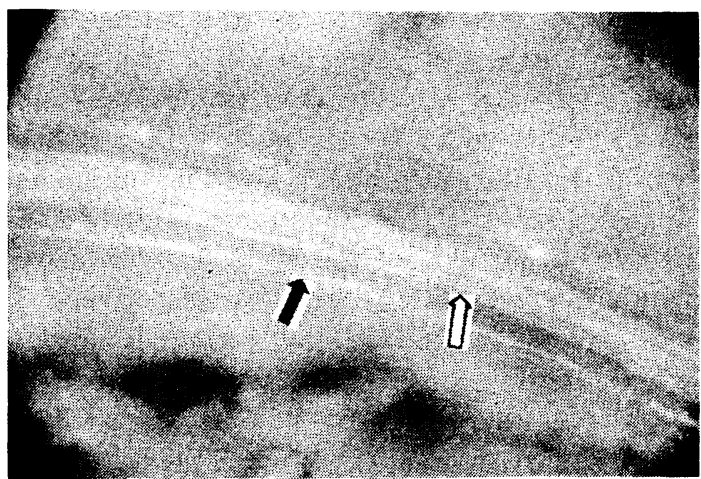

Fig. 5. A longitudinal squashed preparation from the upper portion of an unpollinated style. $\Rightarrow$ shows string-like entities shining yellowish. $\Rightarrow$ shows tube-like entities shining bluish.

helps the pollen grains to germinate easily on stigmas by preventing the stigma surface from high transpiration. According to Konar and Linskens, the secretion of the stigma exudate in Petunia hybryda was influenced by a few factors, such as temperature, light and petal incision (3). In the present experiment, it was shown that the secretion of the stigma exudate in Hyuganatsu was remarkably increased in cross-pollination than in self-pollination. This increase might be a possible reason why pollen germination in cross-pollination was more vigorous than that in self-pollination. Further studies will be necessary to find the substances influencing the pollen germination.

2. The position of pollen tube growth in styles

As mentioned in the introduction, Miwa

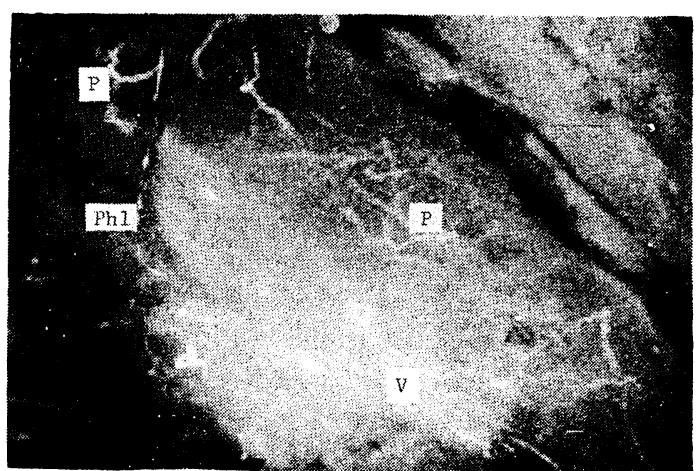

Fig. 6. A longitudinal squashed section of a stigma in Hyuganatsu two days after cross-pollination. P : Pollen tube, Phl : Phloem, V : Vascular bundle.

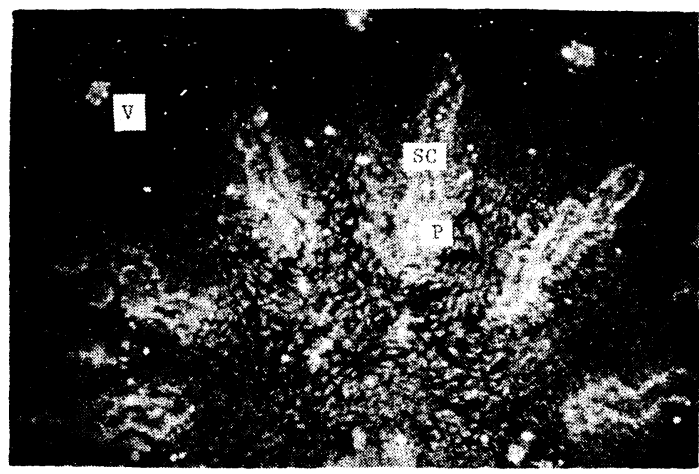

Fig. 7. A transverse section from the upper portion of a style in Hyuganatsu seven days after cross-pollination. P : Pollen tube, SC : Stylar canal, V : Vascular bundle.

stated that the pollen tubes grew through the conductive tissue in the periphery of the vascular bundles (6). But, in the present experiment, several different observations of the unpollinated and pollinated pistils were obtained.

Fig. 4 shows the transverse section of the upper portion of the unpollinated style. Some grain-like entities shone yellowish in the periphery of the vascular bundles as if they were the sections of pollen tubes. Some tube-like entities shining bluish were also observed in the central part of the system. They both can not be the pollen tubes, because their shining tone is apparently different from that of pollen tubes.

Fig. 5 shows the longitudinal squashed preparation from the upper portion of the unpollinated style. Several string-like entities shining yellowish were observed as a bundle. They were surely the same as the grain-like 
entities shining yellowish seen in the periphery of vascular bundles in the transverse sections. In the central part of the system, some tubelike entities shining bluish were present. Under a light microscope, they were observed to have typical spiral patterns on the wall. Such spiral patterns are common to the vessels in many plants. Moreover, the recent work has revealed that the callose deposited in phlcems, root hairs and pubescences is stained brilliant yellow by aniline blue solution $(1,2)$. Therefore, it could be concluded that the tube-like entities shining bluish were vessels and the string-like entities shining yellowish were phloems.

Fig. 6 shows the squashed preparation of the stigma 2 days after pollination. The phloem shining yellowish was clearly observed. Many pollen tubes were also shining yellowish growing in the stigma, but they did not grow in the periphery of vascular bundles.

Fig. 7 shows the transverse section of the upper portion of the style 7 days after crosspollination. The pollen tubes were clearly observed not only in the stylar canal along the wall of stigmatoid cells but also in the parenchymatous tissue around the canal.

Further observations were also made on the middle and lower portions of styles. In these portions, it was observed that all the pollen tubes grew in the stylar canal along the wall of stigmatoid cells.

From these observations, Miwa's suggestion that the pollen tubes should grow in the conductive tissue in the periphery of the vascular bundles should be reconsidered.

According to Webber (unpublished), the pollen tubes grew in the stylar canal. However, Benerdji stated that the growth was intercellular and not in the canal (8). The present observations do not comform to either of them.

3. The growth rate of pollen tubes in styles in self- and cross-pollinations

The numbers of pollen tubes grew through the uppermost, middle and lowermost portions of styles in self- and cross-pollinations are given in Table 1. In cross-pollination, some of the fast growing pollen tubes reached the upper portion of the style in one day. They grew into the middle portion of the style in 3 days and penetrated into ovaries in 5 days. The numbers of pollen tubes at the uppermost, middle and lowermost portions of the style 7 days after pollination were $106.1,16.8$ and 6.2 , respectively. In self-pollination, only a few pollen tubes reached the upper portion of the style within one day, while most of the pollen tubes stayed in stigmas even 7 days after pollination. The numbers of pollen tubes at the uppermost, middle and lowermost portions of the style 7 days after pollination were $5.0,0$ and 0 , respectively.

According to Miwa, the pollen tubes in self-pollination grew easily into ovaries in 7 days, but stayed at the placenta thereafter and did not participate in the fertilization process (6). The results obtained in the present observations disagreed with Miwa's statement.

There are many reports with respect to citrus self-incompatibility $(4,6,8,10,11)$, but are few which described the differece of pollen tube growth between self- and cross-pollination. Ton and Krezdorn observed the growth of pollen tubes in three self-incompatible, citrus varieties, namely Clementine, Minneola and Orland(11). In Clementine and Orland,

Table 1. Numbers of pollen tubes passed through the uppermost, middle and lowermost portions of styles after self- and cross-pollination.

\begin{tabular}{c|l|c|c|c|c}
\hline \multirow{2}{*}{ Pollination } & Portion & \multicolumn{3}{|c}{ Days after pollination } \\
\cline { 3 - 6 } & of style & 1 & 3 & 5 & 7 \\
\hline \multirow{3}{*}{ Self-pollination } & Uppermost & $1.0 \pm 1.5$ & $4.1 \pm 3.0$ & $3.0 \pm 2.8$ & $5.0 \pm 1.9$ \\
& Middle & 0 & 0 & 0 & 0 \\
& Lowermost & 0 & 0 & 0 & 0 \\
\hline \multirow{3}{*}{ Cross-pollination } & Uppermost & $2.4 \pm 2.8$ & $14.4 \pm 6.4$ & $38.5 \pm 13.3$ & $106.7 \pm 20.0$ \\
& Middle & 0 & $0.1 \pm 0.4$ & $3.2 \pm 2.5$ & $16.8 \pm 6.1$ \\
& Lowermost & 0 & 0 & $0.3 \pm 0.7$ & $6.2 \pm 2.6$ \\
\hline
\end{tabular}


the pollen tubes in self-pollination reached the base of the style 7 days after pollination, where in Minneola, the pollen tubes in selfpollination reached only $2 / 3$ of the style. Lange also studied on self-incompatibility of a few citrus varieties, finding that the pollen tubes in self-pollination in Minneola grew 2/5 of the style in 9 days after pollination (4). As compared with these varieties, Hyuganatsu seems to be one of the highly self-incompatible varieties.

\section{Acknowledgement}

The author wishes to express his deep gratitude to Dr. Takashi Tomana, Professor of Kyoto University, for his invaluable guidance throughout the present experiment and also for his kind advice in the preparation of this manuscript. The author is very grateful to Dr. Hiroshi Fujiwara, Assistant Professor of Miyazaki University, for his assistance in scanning electron microscopy.

\section{Literature Cited}

1. Currier, H.B. 1957. Callose substances in plant cells. Amer. J. Bot. $44: 478-488$.

2. FIDALGO, O. 1954. The fluorescence of phloem with aniline blue. Annales di Bot. $24: 431-437$.

3. KONAR, R.N. and H.F. LINSKENS. 1966.
Physiology and biochemistry of the stigmatic fluid of Petunia hybryda. Planta $71: 372-$ 387.

4. LANGE, J. H. 1973. Pollen tube growth in Citrus. Agroplatae 5(3) : 73-77.

5. Martin, F.W. 1959. Staining and observing pollen tubes in the style by means of fluorescence. Stain Technology $34: 125-128$.

6. MiwA, T. 1951. Pollination, fertilization, and fruit drop in Citrus tamurana Hort. Bull. Miyazaki Univ. (Natural Science) $2: 1-67$.

7. OSUMI, M. 1975. Critical point drying method-its principle and practice. Cell 7 (1): 99-117.

8. REUTHER, W., L. D. BACHELOR and H. J. WebBer. 1968. The Citrus Industry 2 : p. 300 .

9. Shiraishi, M., K. Matsumoto, T. NaGaTANI, R. SUZUKI, A. Shigemasu and U. KYAW THAN. 1975. External features of floral and foliar organs of satsuma mandarin (Citrus unshiu Marc.) observed by scanning electron microscopy. J. Jap. Soc. Hort. Sci. $44(2): 107-121$.

10. Soost, R.K. 1964. Self-incompatibility in Citrus grandis osbeck. Proc. Amer. Soc. Hort. Sci. $84: 137-140$.

11. TON, L.D. and A.H. KREZDORN. 1967. Growth of pollen tubes in three incompatible citrus varieties. Proc. Amer. Soc. Hort. Sci. $89: 211-215$. 
ヒウガナツの自家不和合性に関する研究（第 1 報）

走査型電子顕微鏡, 蛍光顕微鏡による柱頭, 花柱内に和ける自家花粉の行動観察

\title{
山下研介
}

(宮崎大学農学部)

\begin{abstract}
摘要
本実験においては，ヒウガナッの自家不和合性に関す 伸長部位について予備調査を行った．その結果，花柱上 る知見を増すことを目的として，二，三の組織形態学的 観察を行い,つぎのような結果を得た。

1. 走查型電子顕微鏡を用いて, 自家受粉区ならびに 他家受粉区（ハッサク花粉受粉）の柱頭上の花粉の行動 を比較観察した．他家受粉区では，柱頭から分泌される 粘液によって受粉された花粉がすみやかに被覆されはじ め，受粉12時間後になると完全に被いつくされてその識 別も不可能となった．これに対して，自家受粉区では， 柱頭粘液による受粉花粉の被覆が遅れ, 受粉 12 時間後 に扔いてもその存在がはっきりと確認できた. 部では花柱溝細胞の内側や柔組織の細胞間隙を伸長し, 花柱中部, 花柱下部ではもっぱら花柱溝壁細胞の内側を 伸長することが観察された。つづに，以上の観察結果に 基づいて，自家受粉区ならびに他家受粉区の花柱内にお ける花粉管の伸長について比較検討を加えた．その結果 他家受粉区では受粉 1 日後には花柱上部にまた受粉 3 日後には中部に到達し, 受粉 5 日後には花柱下部から子 房部へ侵入していた.ところが自家受粉区では受粉 7 日 後になっても花粉管は柱頭内で停滞し, 花柱上部にも到 達していなかった。
\end{abstract}

2. 蛍光顕微鏡を用い，まず花柱内における花粉管の 